\title{
COVID-19 Pandemic Is a Wake-Up Call for Sustainable Local Food Supply Chains: Evidence from Green Restaurants in the USA
}

\author{
Omar Alsetoohy ${ }^{1, *(\mathbb{D}, \text { Baker Ayoun }}{ }^{2}$ and Mahmoud Abou-Kamar ${ }^{1}(\mathbb{D}$ \\ 1 Department of Hotel Management, Faculty of Tourism and Hotels, University of Sadat City, \\ Sadat 32897, Egypt; mahmoud.aboukamar@fth.usc.edu.eg \\ 2 Department of Nutrition, Dietetics, and Hospitality Management, Auburn University, \\ Auburn, AL 36849, USA; bma0002@auburn.edu \\ * Correspondence: omar.alsetoohy@fth.usc.edu.eg
}

check for updates

Citation: Alsetoohy, O.; Ayoun, B.; Abou-Kamar, M. COVID-19 Pandemic Is a Wake-Up Call for Sustainable Local Food Supply Chains: Evidence from Green Restaurants in the USA. Sustainability 2021, 13, 9234. https://doi.org/ $10.3390 /$ su13169234

Academic Editors: Antonietta Baiano and Pasquale Massimiliano Falcone

Received: 16 July 2021

Accepted: 13 August 2021

Published: 17 August 2021

Publisher's Note: MDPI stays neutral with regard to jurisdictional claims in published maps and institutional affiliations.

Copyright: (c) 2021 by the authors. Licensee MDPI, Basel, Switzerland. This article is an open access article distributed under the terms and conditions of the Creative Commons Attribution (CC BY) license (https:/ / creativecommons.org/licenses/by/ $4.0 /)$.

\begin{abstract}
The COVID-19 outbreak has forced customers to shift their food habits to more locally grown products. Therefore, restaurants have begun to provide local food, which is reflected in "farm to fork" or "locally-sourced" or "farm to table" restaurants. Thus, purchasing sustainable food, specifically local food products, has become one of the most salient sustainability practices in restaurants. Therefore, this study seeks to further explore the influences of the Sustainable Local Food Supply Chain (SLFSC) of green fine-dining restaurants on tourist food experiences and destination branding in the USA. Data were analyzed using the partial least square (PLS) technique of a sample of 232 respondents. The findings of this study showed positive impacts of all sustainability dimensions on most consumption values of tourists (i.e., emotional, epistemic, health, taste/quality, etc.). The findings indicated that each sustainability dimension and overall sustainability of the local food supply chain had strong positive effects on destination branding. Finally, tourist food experiences in totality mediated the relationship between the overall Sustainable Local Food Supply Chain and destination branding. This study contributes to the existing literature by developing and validating a scale to measure the sustainability practices of local food supply chains in restaurants to fill this gap in the literature. Additionally, the findings have intimate important theoretical and practical implications.
\end{abstract}

Keywords: local food; sustainability; food supply chain; sustainable local food; consumption value; tourist experiences; destination branding; USA

\section{Introduction}

The Covid-19 outbreak has affected every industry and everyone who lives and works all over the world. Globally, $70 \%$ of hotel staff has been laid off or furloughed due to the very low occupancy rate, eight in 10 rooms remain vacant [1]. In 2020, 197.5 million job losses in the Travel \& Tourism industry achieving a loss of \$5543 billion [2]. Similarly, the National Restaurant Association (NRA) reported that 11 percent of the US restaurants were closed, and the financial loss reached $\$ 240$ billion [3].The restaurant industry has lost almost three times more jobs than any other industry. However, the bad effects of the COVID-9 outbreak, restaurants were known for surviving on tight margins, trying to make do with limited take-out and home delivery. Recently, most of the governments in different countries published guidelines for restaurants to re-open their dining rooms partially. Unfortunately, neither appears to be enough to ensure survival for most restaurants just staying afloat. In addition, restaurants are facing a pivotal challenge related to the supply of their operating food materials. For instance, Wendy's restaurants declared that some of its traditional burger items are unavailable, about one in five of Wendy's restaurants are out of beef, because of beef supply shortage [4]. Consequently, sourcing local food products 
in restaurants makes perfect business sense during and post the COVID-19 pandemic to decrease the pressure of international food supply chain (FSC) shocks.

Undoubtedly, the COVID-19 outbreak has forced customers to change many of their food habits and consumption values. For example, customers start shifting their food tastes to more locally grown products to reduce the perceived health risk. This was confirmed by Amy McCann, co-founder of Local Food Marketplace, a farm software company, who stated that "people feel that foods that have been produced at their local farm are less prone to viral spread" [5]. Additionally, Bryła [6] argued that farmers' markets have the potential to encourage the sustainable production and consumption of agricultural products. Considering customers' awareness of the items they consume, including food origin [7], pursuing natural, organic, sustainable, locally produced foods are of paramount importance [8]. This increased awareness has led to increasing interest in local foods for restaurant customers $[8,9]$. For instance, the NRA's survey reported that around $70 \%$ of the respondents were willing to eat in locally sourced restaurants over those not locally sourced, and about $65 \%$ of the respondents requested more salubrious items in the restaurants [3], which ranked locally sourced foods to be a top culinary trend over the past five years [8,9]. Thus, estimates of local food sales, in the United States, jumped to $\$ 20$ billion in 2019 [10].

Typically, restaurant patrons prefer local foods due to its benefits which include: healthy food, a better environment, and greater social justice [11,12]. Other benefits include freshness, short transport, and security [13]; delicious taste and a better understanding of the FSC [9]. Consequently, many restaurant operators across the world are already improvising to adapt to the new reality through adjusting their menus to include local ingredients, which will endure far beyond the current COVID-19 crisis [14]. Additionally, restaurants have started featuring local food ingredients, mirrored by "Farm-to-fork" or "Locally sourced" or "Farm-to-table" restaurants [15]. Providentially, restaurants that featured local ingredients or sustainable local foods, are at least going to weather the storm of the COVID-19 pandemic a little bit and could achieve a speedy recovery from the current crisis and competitive edge. This is confirmed by the NRA report which stated that "local sourcing, healthy options, and eco-friendly food are increasingly important to consumers, .... the availability of these options factors directly into customers' choice of a restaurant" [3].

Since the sustainability practices are considered determinants of customer loyalty, their willingness to pay a premium, decision-making process [16], and repeating visits [17], sustainable food purchasing, specifically local food products, has become one of the most salient sustainability practices in the restaurants $[9,15]$. However, local foods were usually linked to sustainable and healthy production and consumption patterns [18], the linkage between local food and sustainability remains discordant [19]. Consumption of local foods or locally growing doesn't guarantee the ecological sustainability of the agricultural systems in terms of chemical, energy, and water-intensive farming activities $[19,20]$. For instance, ref. [21] argued that the distance traveled by food is a weak measure of food production's environmental effects. While McWilliams [22] acknowledged that the methods utilized to produce local foods and their effects on the ecosystem and biodiversity are unknown. Consequently, the more industrial farming methods are used by local farmers, which include widespread use of agrochemicals, and pesticides, the more negative impacts on the environment, biodiversity, local agricultural workers, and the local community will be found [23].

Recently, the US local food associations are working to promote the consumption movement of locally produced foods and to support sustainable food production methods to conserve both the local and global environments. Thus, organic local food is an alternative solution to combine and achieve local food and local economic, social, and environmental benefits [23]. Similarly, organic menus were found to positively affect corporate social responsibility perceptions [24]. Accordingly, this study adopts the term Sustainable Local Food (SLF) to refer to the benefits of both local food and sustainability. This study argues that SLF is an alternative and innovative way of integrating local food with economic, social, and environmental benefits in the hospitality and food industry. 
Ethics, environment, social responsibility, and sustainability are motives to residents to consume local foods. In the same manner, the discovery and consumption of local foods and beverages have been given increasing attention by tourists, which made food an essential pillar of the tourist experience, providing various sources of special meaning and pleasure. Certain travelers and tourists determine their destination according to the gastronomy menus [25]. However, although the sustainability of local food has been under scrutiny [7], restaurant customers are increasingly searching for local food experiences and are tended to pay a premium for positive experiences [26]. Moreover, local food would enhance the destination image and optimize its attractiveness because it serves as a symbolic brand at the destination [27].

Despite the active study of tourism local food, many questions associated with tourist's local food consumption and experiences remain unsolved [28]. Therefore, this study seeks to further explore the influences of the Sustainable Local Food Supply Chain (SLFSC) of green fine-dining restaurants on tourist food experiences and destination branding as shown in Figure 1. Hence, the following research questions guide this study:

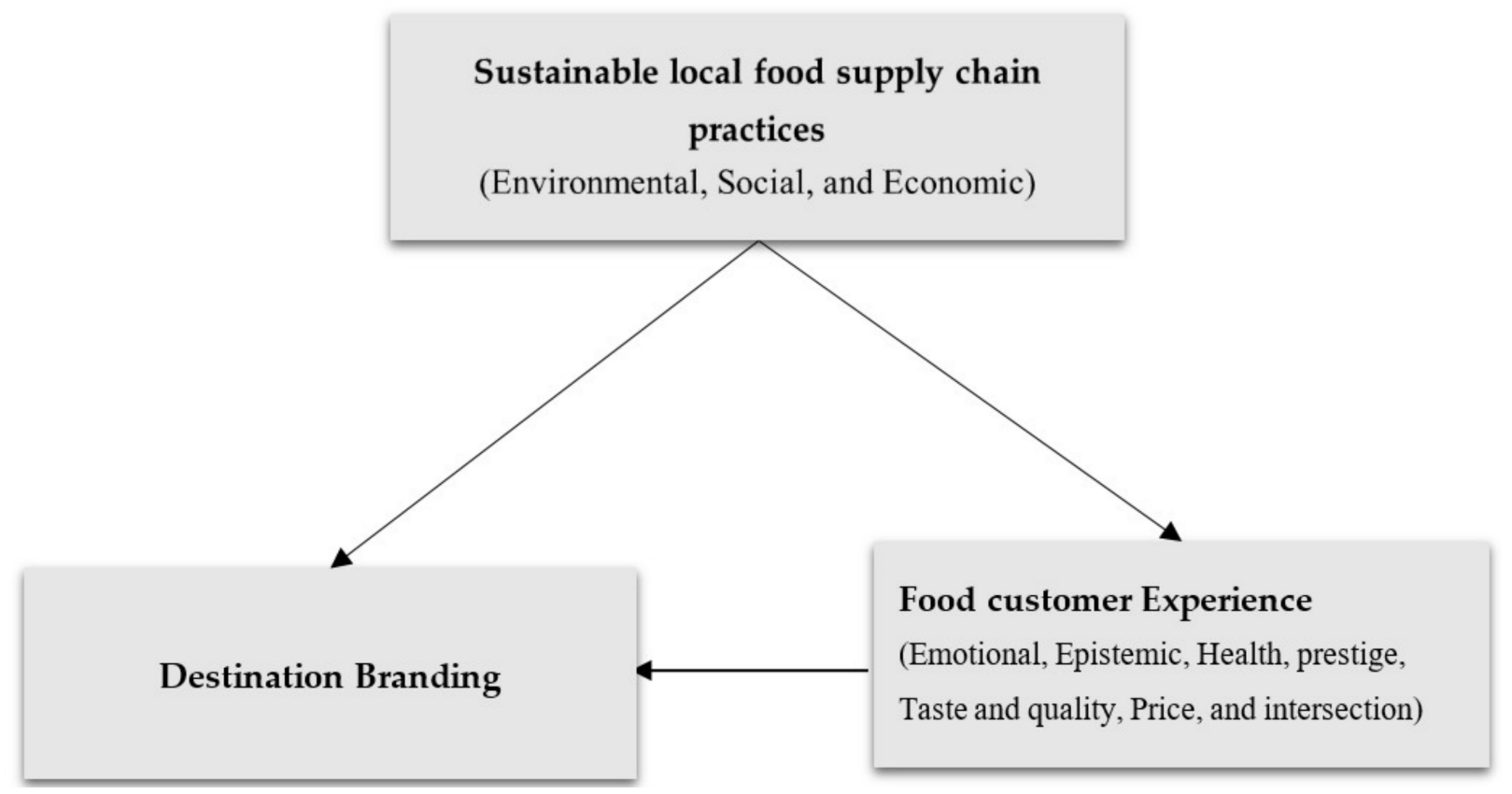

Figure 1. The proposed framework of the study.

Research question one: To what extent do green fine-dining restaurants adopt sustainable local food supply (SLFS) practices in their food supply chain management?

Research question two: To what extent does each dimension of sustainable local food supply (SLFS) practices (i.e., environmental, social, and economic) affect tourist food experiences and destination branding?

Research question three: To what extent does the overall sustainability of local food supply chain affect tourists' overall food experiences and destination branding?

Research question four: To what extent do tourists' overall food experiences influence destination branding?

Research question five: To what extent do tourists' overall food experiences mediate the influence of the overall sustainability of local food supply chain (SLFS) on destination branding? 


\section{Literature Review and Hypotheses Development}

\subsection{Local Food in the Restaurant Food Supply Chain}

The locality of foods is a concern of residents and travelers who are showing an increased interest in locally grown/produced foodstuffs [12]. The concept of purchasing locally sourced or produced foods in the US was introduced in the 1930s, mirrored by branding programs such as "State grown", "locally grown", "Pride of New York", "Pick Tennessee Products", and "Ohio Proud". Such programs now exist in most US states [29]. In 2005, in San Francisco, California, the website Locavores.com has been launched by a group of "foodies" who called "localvores" or "locavores" to support consuming local food. In 2009, North Carolina launched the "10\% North Carolina" campaign, which aims to stimulate local economic development by creating jobs and promoting demand for state products. More than 4600 people and 543 companies, including 76 restaurants, registered to support the event through the following website: http:/ /www.nc10percent.com (accessed on 12 June 2020). They pledged to spend $10 \%$ of their food budget on local food supplies. As a result of this campaign, more than 14 million U.S. dollars were used to purchase locally grown agricultural products [23]. However, given the excessive literature of local food importance in various disciplines, there are two challenges: first, the notion of "local food" is still ill-defined, and second, there is no standardized method to measure the effects of local foods on the sustainability of FSC [11,29].

Considering customers' awareness of food origin, inputs within production, labor standards implemented, treatment of animals, and effects of food production on the environment [7], pursuing natural, organic, and locally produced foods is of paramount importance [8]. This escalating customer's awareness has led to an increasing interest in local food consumption in restaurants $[8,9,12]$, accompanied by customer's willingness to pay a premium for local foods, up to $4-5 \%$ more [30], to compensate social and environmental costs of production, processing, and distribution of local foods [31]. Further, the consumption of local food has projected CAD 11 billion in 2012 [32].

Conventional food actors, i.e., food stores, restaurants, hotels, etc., have started to adopt techniques that encompass local food demand due to the strong appeal of local foods among patrons from tourists [11,31]. Meeting this demand by food actors, therefore, becomes a factor contributing to demand attraction. Evidence from the field study is that family, casual, and fine-dining restaurants shop around for, other food suppliers, local suppliers, by $58 \%, 60 \%$, and $74 \%$, besides, $46 \%, 45 \%$, and $51 \%$ of the purchased food products were from local suppliers respectively [3].

In Switzerland, the study of DiPietro et al. [33] found that more than $67 \%$ of respondents preferred locally sourced products in restaurants and around $71 \%$ of the respondents were intending to re-visit the locally-sourced restaurants. This is confirmed by the NRA report which stated that "local sourcing, healthy options, and eco-friendly food are increasingly important to consumers, and a majority of them say the availability of these options factors directly into their choice of a restaurant" [3]. Given the fact that restaurants are customer-oriented and highly sensitive to their preferences, restaurants have increased their local food suppliers to purchase locally grown and produced foods [34]; to feature local food ingredients [15]; and to gain more profits [30]. Thus, a locally-sourced restaurant could be defined as any restaurant that procures food primarily or exclusively from local producers [15] and/or local markets or suppliers [34].

However, the documented benefits of sourcing local foods within the FSC in the hospitality industry establishments such as the possibility of purchasing smaller quantities, fresher and safer foods, high customer satisfaction, good public relations, support to the local economy, and knowledge of product sources and production methods [32,35], obstacles were identified. These challenges include inconsistencies in quality, insufficient availability, and transportation and delivery issues; purchasing, production, and food prices [30]; low volumes of available local products [36], payment procedure conflicts, reliable suppliers, lack of knowledge about local sources, inconvenient ordering, limited quantity and availability, variable cost, service, inadequate distribution systems, and 
additional time to process foods in the operation [34-36]. Moreover, the geographic location of restaurants determines the availability of and access to local food items required to the restaurants' menu [32]. Sharma et al. [35] concluded that, in general, lack of communication and a weak relationship between local food producers and restaurants are the main barriers for locally-sourced restaurants.

In conclusion, truly LFSC in foodservice establishments would be considered a contributing factor to these establishments to: attract local food demand, acquire more profits, and achieve a competitive advantage, market restaurant menu, have a strong relationship with customers and local producers, suppliers and community, and finally to contribute to the corporate social responsibility.

\subsection{Sustainable Local Food Supply Chain in the Restaurant Industry}

Sustainability is defined as a situation in which the needs of the present generation are met without sacrificing the ability and opportunity of future generations to meet their needs [37]. The increased interest in sustainability in general, and the food industry in particular, is due to the increased effects of climate change, water usage, toxic discharges, environmental change, and food demand of growing consumers [38,39]. For instance, the generated food waste of the US restaurant sector, about 11.4 million tons annually, and discarded foods within the FSC generate methane that pollutes the environment and engenders greenhouse gas emissions [39]. Also, about $15 \%$ to $28 \%$ of GHG emissions are generated from the whole FSC. Thus, deeper concerns about the environment and intentions to pay a premium for green services by consumers were found $[40,41]$.

A sustainable FSC is rooted in the theory of sustainability and supply chain management. Sustainable supply chain management is defined as "the management of material and information flows as well as cooperation among companies along the supply chain while taking goals from all three dimensions of sustainable development, i.e., economic, environmental and social, and stakeholder requirements into account" [42]. The main reason for implementing sustainable initiatives, specifically in the food supply chain management, is that organizations can generate more business opportunities than their competitors if they can address environmental, economic, and social considerations successfully. For instance, sustainability allows hospitality operators to achieve corporate responsibilities, higher efficiency in FSC management performance and resources usage, a higher financial performance (i.e., return on assets and equity) [43]. In this vein, Hanifan et al. [44] confirmed that setting up sustainable supply chain management can save costs, identify new income sources, and optimize brand value. Otherwise, nonfulfillment of the economic, environmental, health, and social considerations within the worldwide industrial FSC increased local food initiatives in Europe and North America [20]. Subsequently, more attention to the integration of the environmental, social, and economic considerations has been paid to the food procurement by food service operators [45] through procuring locally-sourced food products within the restaurant FSC [12]. This ranked local foods to be one top visible sustainable practices in the food service establishments [9]. Typically, local foods have been frequently associated with sustainable and healthy production and consumption patterns [31].

LFSC products outperformed the global food system in areas of sustainability (e.g., territoriality, nutrition, animal welfare, biodiversity) [11], which became a more sustainable alternative to global food [46]. Local food is still regarded as potentially enhancing sustainability in the hospitality and tourism industry [47]. Sustainability dimensions in the LFSC include information about the environmental (planet), social (human health, safety, and welfare), and economic (profit) context. Thus, a sustainable food system is " $a$ collaborative network that integrates several components to enhance a community's environmental, economic and social well-being" [48]. Xu and Gursoy [16] revealed that the environmental context focuses on minimizing the negative environmental impact of FSC operations. The social dimension, on the other hand, means maximizing the social well-being of employees, customers, suppliers, and all other supply chain stakeholders affected by the operation of the supply chain. Finally, the economic dimension maintains long-term benefits while 
minimizing creation and negative environmental and social consequences. Hence, the characteristics of the LFSC accord with the sustainability dimensions: short distances between producers and consumers; low external input and organic production methods; sustainable production, distribution, and consumption [19].

In the same context, previous research in the hospitality industry introduced the documented benefits of local foods in the restaurant FSC as an indicator of local foods sustainability. For instance, Björk and Kauppinen-Räisänen [12] stressed that residents typically turn to the local food due to the social, environmental, and economic responsibility to optimize local food sustainability by consuming locally grown and produced food. Also, Pearson et al. [49] argued that local foods shorten the FSC which, in turn, reduces the energy used or carbon footprints of the entire FSC, in addition to a reduction in food packaging (environmental dimension). Local food boosted trust and connection between the LFSC parties, allowing inhabitants of the local community to better integrate (social dimension). Finally, the earnings from LFSC parties and destination branding opportunities are reinvested in the local economy, resulting in economic growth (economic dimension). Consequently, purchasing and consuming local foods was associated with the environmental sustainability concept through reducing carbon footprint via shorter transportation distances $[8,15,30,50,51]$. In Finland, rural consumers believe that local food is a way to support local production and create economic well-being in a community; For urban consumers, local food is closely related to animal welfare, the environment and health. Both rural and urban consumers believe that short transport distances are a reason for local food preferences [52]. Roy et al. [19] mentioned that local food orientation by tourists and travelers enhanced local agricultural practices and foodways. Buying local food has a multiplier impact, benefiting the local economy by supporting and enhancing destination brands, creating and innovating agricultural diversification, and creating new export markets [46]; and creating job opportunities for locals [12,30]. The study of Sims [53] concluded that local food covers everything from concerns about environmental and social sustainability to consumer demand for safe, unique and traceable food.

\subsection{Tourist Food Experiences}

Customer experience "originates from a set of interactions between a customer and a product, a company, or part of its organization, which provoke a reaction" [54]. The importance of food items to tourist experiences is considered incontestable and widely acknowledged by scholars $[53,55]$ because tourists have to dine at an outlet during the journey [56]. Discovery and consumption of local food and beverages are given increasing attention by tourists, which made food an essential pillar of the tourist experience, providing various sources of special meaning and pleasure. Moreover, certain travelers and tourists determine their destination according to the gastronomy menus [25] which affects the destination economy [27]. Food tourism was defined by Hall and Mitchell [57] as "a visit to primary and secondary food producers, food festivals, restaurants, and specific locations for which food tasting and/or experiencing the attributes of a specialist food production region are the primary motivating factors for travel" (p. 308). As a consequence, previous studies have identified food consumption by tourists as the perceived benefit or usefulness of consuming local food at a destination [58-61]. However, the excessive literature on the tourist experience and food experience [25,28,55,62-67], there are no globally accepted dimensions for food experiences. For instance, Hansen et al. [62] mentioned that product, interior decoration, contact with staff, contact with customers, and the occasion are the five key themes that influence the restaurant experience. Also, Matson-Barkatand Robert-Demontrond [25] explained the customer food experience in terms of sharing experiences, family togetherness and transmission, cultural guidance, and customer-to-customer interaction. Additionally, Kim and Eves [63] determined five motivations for tourists to consume local food: excitement, cultural experience, sensory appeal, interpersonal relationship, and health concern. Thus, we grouped the extant literature of local food consumption experiences into three research streams. The first stream focuses 
on the motivational dimensions which include, but are not limited to, physical, cultural, interpersonal, and status and prestige motivators $[56,63,68,69]$. While, the second stream focuses on the attributes and benefits of the local food [8,52]. Finally, the third stream focuses on the attitudes and behaviors of the tourist toward local foods in the hospitality sector $[9,30]$.

Recently, it was argued that tourist food experiences could be measured in terms of values $[8,27,70]$. Values are abstract concepts that are not specific to an object or situation, and they influence an individual's selective perception and evaluation [8]. Hauser et al. [70] stated that values have been linked to specific food choice behaviors such as consumer's willingness to purchase organic foods which are determined by the level of the ethical and moral values of the consumers. Also, personal values (e.g., security, warm relationships with others, self-fulfillment, a sense of belonging, excitement, etc.) have been addressed to measure consumers' local food consumption experiences [8] and consumer perceptions of food benefits [71]. Accordingly, Choe and Kim [27] introduced seven consumption values (i.e., emotional, epistemic, health, prestige, taste and quality, price, and interaction values) based on the consumption value theory to measure tourists' food experiences. In so doing, this study will depend on the conceptualized multidimensional model of local food consumption by Choe and Kim [27] to measure tourist food experiences in green fine-dining restaurants.

\subsection{Destination Branding}

Destination image was recognized as "the individual's mental representation of knowledge, feelings, and global impressions about a destination" [72]. The formation of a destination image constitutes the core of branding a destination [73]. This image construction also emerges from the point of view through destination brand search strategies and actions [74,75]. Barnes et al. [76] defined the destination brand as a complex experiential brand that could be used as a marketing tool to: represent the potential experience of tourists visiting that destination [77]; create positive images of tourist attractions; and meet tourists' needs [26].

To brand a destination, marketers need to choose a cohesive mix of branding elements to establish a unique destination identity [78]. The gastronomic experience of visitors constitutes a powerful marker for destination brand image, and it becomes a strategic interest focus for restaurant industry professionals [59,74,79]. The food at the destination has a functional and symbolic value for the tourist. It is a source of satisfying hunger and a way to experience the local gastronomic culture, local gastronomy and activities related to gastronomic festivals, events, tourism and cooking courses. In the last decades, the image of the destination food is integrated into one of the various structures of the destination brand, as a component that adds value to the overall destination image, and did not explicitly examine it in the context of branding [80]. Recent research studies have identified food as a core element to brand a destination $[73,79,80]$, as it is perceived as an intangible cultural heritage inspiring tourists to "purposely travel to a given destination because of its food image" [80].

Local food is a critical part of location branding and marketing as it connects many aspects of the destination experience such as locality, gastronomy, culinary, and experiences [81]. The consumption of local foods helps in the creation of "identity", which increases the importance of the relationship between food and destination. Thus, consumption of local food was found to have a direct effect on branding a destination [82,83]. Therefore, the quality and uniqueness of local food products help support destination brand and image [84], and help serve local food as a symbolic brand at the destination $[27,84]$. Prior research studies showed that ecological elements determine consumer preferences on foods that are perceived to be more eco-friendly and natural $[84,85]$. Thus, the importance of sustainable local food to marketing a destination is paramount. Sustainable local food seems to play a key role in what has been defined typically as "alternative," "ethical" or even "environmental" consumption to optimize destination branding [46]. Thus, the following hypotheses are proposed: 
Hipothesis 1 (H1). The environmental dimension of sustainable local food supply chain in the green fine-dining restaurants is positively affecting H1.1. emotional; H1.2. epistemic; H1.3: health; H1.4. prestige; H1.5. taste/quality; H1.6. price; and H1.7. interaction values of tourists and H1.8. destination branding.

Hipothesis 2 (H2). The social dimension of sustainable local food supply chain in the green fine-dining restaurants is positively affecting H2.1. emotional; H2.2. epistemic; H2.3: health; H2.4. prestige; H2.5. taste/quality; H2.6. price; and H2.7. interaction values of tourists and H2.8. destination branding.

Hipothesis 3 (H3). The economic dimension of sustainable local food supply chain in the green fine-dining restaurants is positively affecting H3.1. emotional; H3.2. epistemic; H3.3: health; H3.4. prestige; H3.5. taste/quality; H3.6. price; and H3.7. interaction values of tourists and H3.8. destination branding.

Hipothesis 4 (H4). The overall sustainability of sustainable local food supply chain in the green fine-dining restaurants is positively affecting tourists' overall food experiences.

Hipothesis 5 (H5). The overall sustainability of local food supply chain in green fine-dining restaurants is positively affecting the destination branding.

Hipothesis 6 (H6). Tourists' overall food experiences are positively affecting destination branding.

Hipothesis 7 (H7). Tourists' overall food experiences mediate the influence of the overall sustainability of local food supply chain on destination branding.

\section{Materials and Methods}

\subsection{Sampling and Data Collection}

Respondents were patrons of the green fine-dining restaurants in the USA. All green fine-dining restaurants certified by the GRA in the USA, representing virtually all states of the USA ( $n=19$ restaurants), were considered the sample of the study. In the restaurant industry, several green certification programs exist such as Green Kitchen Certifications, Green Seal, and GRA. Among these certification programs, GRA certification was chosen because its standards (i.e., eight environmental categories) are closely related to green attributes proposed by researchers (e.g., sourced at least three local food items). Additionally, these restaurants implement sustainability practices identically to add extra value to the guest experiences by serving a variety of locally sourced meals. Due to the continued assessment of these green practices by the GRA and the high rating scores, via TripAdvisor, from customers, these sustainable green practices are not considered greenwashing practices. Greenwashing is a practice used to make a restaurant appear more environmentally friendly than it actually is, by spending more money, time, and effort on marketing its products or services as "green", rather than actually minimizing its negative impact on the environment. The information of the green fine-dining restaurants (i.e., names, location, website information, or direct phone inquiry) were drawn from the website of the American Green Restaurants Association website. The online survey was employed through Amazon's Mechanical Turk (MTurk), targeting only 250 patrons of the predetermined nineteen restaurants in the USA. MTurk is considered fast, low cost, flexible, and more representative, and it allows researchers to target specific populations [86]. Screening questions were used to ensure compliance with the study's requirements, i.e., tourists (internal or overseas) and ate out over twice in these restaurants within the last three months. The online survey was available on the MTurk Platform from 24 February to 10 March 2021, and each participant was compensated with one USD. Of the 250 respondents who filled the online survey out, only 232 (response rate $=0.928 \%$ ) were eventually usable. Eighteen responses, twelve missing data and six bias answers, were excluded. Respondents did not answer more than eight questions in the same survey, whereas the six bias answers almost had one choice for all questions. The demographic profile of the participants of the study is presented in Table 1. 
Table 1. Sample characteristics.

\begin{tabular}{|c|c|c|}
\hline Characteristics & Frequency & Percent \\
\hline \multicolumn{3}{|c|}{ Number of visits to the restaurants } \\
\hline Three visits & 33 & 14.2 \\
\hline Four visits & 129 & 55.6 \\
\hline Five visits & 31 & 13.4 \\
\hline More than five visits & 39 & 16.8 \\
\hline \multicolumn{3}{|c|}{ Gender } \\
\hline Female & 89 & 38.4 \\
\hline Male & 142 & 61.2 \\
\hline Prefer Not to Disclose & 1 & 0.4 \\
\hline \multicolumn{3}{|c|}{ Marital status } \\
\hline Single & 104 & 44.8 \\
\hline Married & 124 & 53.4 \\
\hline Separated & 4 & 1.7 \\
\hline \multicolumn{3}{|c|}{ Age } \\
\hline 19-30 Year & 131 & 56.5 \\
\hline 31-40 Year & 62 & 26.7 \\
\hline 41-50 Year & 24 & 10.3 \\
\hline 51-60 Year & 11 & 4.7 \\
\hline Over 60 Year & 4 & 1.7 \\
\hline \multicolumn{3}{|c|}{ Education } \\
\hline Less Than High School & 1 & 0.4 \\
\hline High School Graduate & 12 & 5.2 \\
\hline Some College & 28 & 12.1 \\
\hline Two Years Degree & 16 & 6.9 \\
\hline Bachelor & 112 & 48.3 \\
\hline Professional Degree & 19 & 8.2 \\
\hline Master Degree & 38 & 16.4 \\
\hline Doctorate & 6 & 2.6 \\
\hline \multicolumn{3}{|c|}{ Country } \\
\hline Brazil & 3 & 1.3 \\
\hline Canada & 33 & 14.2 \\
\hline Chile & 2 & 0.9 \\
\hline China & 2 & 0.9 \\
\hline Egypt & 2 & 0.9 \\
\hline France & 3 & 1.3 \\
\hline Germany & 2 & 0.9 \\
\hline Ghana & 1 & 0.4 \\
\hline India & 64 & 27.6 \\
\hline Italy & 2 & 0.9 \\
\hline Japan & 3 & 1.3 \\
\hline Mexico & 7 & 3.0 \\
\hline Pakistan & 2 & 0.9 \\
\hline Prefer Not to Disclose & 1 & 0.4 \\
\hline Saudi Arabia & 1 & 0.4 \\
\hline Scotland & 1 & 0.4 \\
\hline South Korea & 2 & 0.9 \\
\hline Spain & 3 & 1.3 \\
\hline Trinidad & 2 & 0.9 \\
\hline Turkey & 2 & 0.9 \\
\hline UK & 12 & 5.2 \\
\hline USA & 82 & 35.3 \\
\hline
\end{tabular}




\subsection{Measurements}

To test the research hypotheses, a quantitative approach was employed with an online survey. The questionnaire was developed based on an in-depth review of related studies. The questionnaire contains four sections; namely, SLFSC, food experiences, destination branding, and respondents' profiles. However, in the active study of sustainability practices in the FSCM in general, there is no accepted measurement scale that measures the SLFSC practices, specifically in the hospitality industry. Thus, this study developed a questionnaire specifically for the SLFSC based on the 88th item scale of Modica et al. [86], which measures sustainable supply chain management. We shortened and modified the measurement of Modica et al. [86], to 33 items. Hence, the first section of the questionnaire includes the sustainability practices: environmental (12 items), social ( 13 items), and economic ( 8 items). The second section consists of 7 constructs ( 28 items) to measure tourist food experiences adapted from [27]: emotional (6 items), epistemic (5 items), health (4 items), prestige ( 4 items), taste and quality (5 items), price ( 2 items), and interaction ( 2 items) values. Also, the third section of the destination branding contains one construct (5 items) retrieved from [27]. The last section contains the respondents' profiles. Additionally, all of the items for the questionnaire were measured by five-point Likert scales ranging from "strongly disagree $=1$ " to "strongly agree $=5$ "). The online survey was created and conducted electronically using the MTurk platform. To minimize the scale Modica et al. [86] to 33 items, we deployed two techniques. First, we reviewed the measurements of FSC, green practices, and sustainability in the literature to determine the most repeated and significant items in the scale of [86]. Second, the first initial draft of the questionnaire was sent to seven academics and nine experts in the field of FSC and sustainability in the USA and Egypt. This draft was structured into three main dimensions with three sub-dimensions. The majority of the academics and experts, fourteen persons, recommended establishing only three dimensions, environmental, social, and economic, to measure the SLFSC, and they rebooted 8 items as well as minor amendments in the language. Thus, the second initial draft, which consisted of 36 items, was tested by one hundred students. After fixing the slight modifications on the second initial draft, a refined draft of the questionnaire in English was distributed to thirty students and forty restaurant patrons for the pilot test in Auburn Alabama, USA. Based on the results of the pilot study, three items were removed due to the strong correlation relationship.

In this study, the SLFSC measurements were modified/extended from literature to fit with the research objectives. Thus, the SPSS, version 24 , was run to test the validity and reliability of the instrument. Exploratory factor analysis (EFA) is used to: determine the validity of the instrument; reduce the number of sustainability practices to some extent and avoid cross-loading of variables. In addition, Cronbach's alpha is used for reliability testing. The data are first checked to ensure their suitability for factor analysis. The overall significance of the correlation matrix was 0.000. Bartlett's test of Sphericity was 9187.23, which is very significant $(p=0.000)$ in rejecting the hypothesis that the correlation matrix is an identity. The value for the Kaiser-Meyer-Olkin (KMO) model was 0.959 confirming the adequacy of the sample. The value of 0.963 for Cronbach's Alpha concluded the satisfactory level of internal consistency of the scale. The results showed that the data have a significant correlation and are suitable for factor analysis.

EFA with VARIMAX orthogonal rotation identified three constructs, namely environmental, social and economic, from the independent variables with an eigenvalue greater than one, which altogether explained $78.7 \%$ of the total variance, higher than the minimum value of $60 \%$ [87]. As presented in Table 2. The factor loading of each element loaded under each factor was higher than the threshold of $0.55[88,89]$. Additionally, the cross-loadings of items on other factors were under the suggested value of 0.3 [90]. 
Table 2. The rotated component matrix of sustainability dimensions of LFSC.

\begin{tabular}{|c|c|c|c|}
\hline \multicolumn{4}{|c|}{ Rotated Component Matrix } \\
\hline & Social & Environmental & Economic \\
\hline SOC7 & 0.905 & 0.167 & 0.115 \\
\hline SOC1 & 0.897 & 0.220 & 0.107 \\
\hline SOC10 & 0.896 & 0.153 & \\
\hline SOC2 & 0.894 & 0.228 & \\
\hline SOC11 & 0.889 & 0.186 & 0.108 \\
\hline SOC8 & 0.880 & 0.173 & \\
\hline SOC12 & 0.879 & 0.172 & \\
\hline SOC4 & 0.878 & 0.221 & \\
\hline SOC9 & 0.866 & 0.216 & 0.180 \\
\hline SOC3 & 0.856 & 0.200 & \\
\hline SOC6 & 0.855 & 0.137 & 0.110 \\
\hline SOC5 & 0.844 & 0.129 & \\
\hline SOC13 & 0.749 & 0.202 & \\
\hline ENV1 & 0.165 & 0.884 & 0.130 \\
\hline ENV3 & 0.217 & 0.865 & 0.117 \\
\hline ENV10 & 0.220 & 0.861 & 0.155 \\
\hline ENV9 & 0.245 & 0.851 & \\
\hline ENV7 & 0.162 & 0.844 & \\
\hline ENV12 & 0.247 & 0.837 & 0.178 \\
\hline ENV5 & 0.176 & 0.834 & \\
\hline ENV4 & 0.194 & 0.831 & 0.141 \\
\hline ENV11 & 0.196 & 0.818 & 0.130 \\
\hline ENV6 & & 0.814 & 0.236 \\
\hline ENV2 & 0.164 & 0.811 & 0.171 \\
\hline ENV8 & 0.182 & 0.769 & 0.243 \\
\hline ECO4 & 0.108 & 0.153 & 0.897 \\
\hline ECO1 & 0.119 & 0.163 & 0.894 \\
\hline ECO5 & & 0.194 & 0.878 \\
\hline ECO7 & 0.139 & 0.151 & 0.871 \\
\hline $\mathrm{ECO} 3$ & & 0.207 & 0.862 \\
\hline ECO8 & & 0.102 & 0.861 \\
\hline ECO6 & & & 0.858 \\
\hline ECO2 & 0.187 & 0.243 & 0.848 \\
\hline
\end{tabular}

\subsection{Data Analysis and Hypothesis Testing}

Led by the hypotheses, data were analyzed using the partial least square (PLS) technique. The PLS is considered a well-established technique for estimating path coefficients in structural models. PLS has become widespread in hospitality and tourism research for a variety of reasons [89]. For instance, PLS provides very robust model estimations with data that have normal as well as extremely non-normal distributional properties which enforce less restrictive assumptions about data normality [87]. Moreover, PLS is more suitable for small sample sizes, prediction, and theory development. Additionally, PLS is suitable for models that have large numbers of indicators [87]. The concept of this study is the sustainability of LFSC, which is relatively new to hospitality. Also, the total number of the model's indicators is 66 . Thus, due to these arguments, the research hypotheses were tested using the SmartPLS-SEM version 3.2.8. A Two-step process was deployed to assess the theoretical model using this software; the measurement model and the structural model $[87,91,92]$.

\subsection{The Measurement Model (Outer Model) Quality}

The study examined both validity and reliability for all latent variables through assessing the measurement model of this study. Composite reliability (CR), which is more suitable for PLS-SEM, was used to examine the internal reliability of the constructs [91]. Moreover, the factor loadings of the indicators, $\mathrm{CR}$, and the average variance extracted 
(AVE) have been considered to establish convergent validity. The discriminant validity was assessed through the square roots of AVE and the Heterotrait-Monotrait (HTMT) ratio of correlation. The collinearity of all the constructions was also verified using the variance inflation factor (VIF).

Table 3 illustrates that the $\mathrm{CR}$ for all latent variables (LVs) in the measurement model was greater than the threshold of 0.7 [91]. Therefore, the results demonstrate that our measurement model had internal consistency and was reliable. Additionally, all of the item loadings exceeded the recommended value of 0.7 , the construct $C R$ values were greater than 0.7 and the AVE values exceeded the threshold value of 0.6 [91]. Therefore, convergent validity was established. The discriminant values did not violate the threshold value (0.85) of HTMT [93] and all constructs correlations were lower than the square root of AVE of their respective constructs $[89,94]$, therefore, discriminant validity was established; see Tables 3 and 4. The full VIF values for constructs ranged between 1.4-6.6. Except for EMO6, which was removed, all indicators were under the floor of 10 confirming that there is no multicollinearity problem between the constructs [90]. Thus, all seem to attest to the reliability and validity of the scales.

Table 3. Item loadings and construct reliability and validity.

\begin{tabular}{|c|c|c|c|c|}
\hline Construct/Item & $\begin{array}{c}\text { Item } \\
\text { Loadings }\end{array}$ & $\begin{array}{c}\text { Cronbach's } \\
\text { Alpha }\end{array}$ & CR & (AVE) \\
\hline $\begin{array}{l}\text { Environmental: Overall, I believe that this restaurant... } \\
\text { ENV1: Purchases locally environmentally friendly food products. } \\
\text { ENV10: uses natural local food. } \\
\text { ENV11: uses seasonal local foods } \\
\text { ENV12: uses local organic certified foods. } \\
\text { ENV2: uses natural cleaning alternatives (e.g., lemon juice, vinegar, salt). } \\
\text { ENV3: avoids food products that are not recyclable. } \\
\text { ENV4: avoids purchasing overly packaged food products. } \\
\text { ENV5: uses recyclable packing materials or containers for foods. } \\
\text { ENV6: reduces the amount of food waste per guest visit. } \\
\text { ENV7: implements waste-disposal practices. } \\
\text { ENV8: develops an environmental policy, specifically for sustainable local food. } \\
\text { ENV9: provides a safe and healthy environment. }\end{array}$ & $\begin{array}{l}0.90589 \\
0.90218 \\
0.85043 \\
0.89167 \\
0.85029 \\
0.89993 \\
0.86373 \\
0.83865 \\
0.84920 \\
0.85980 \\
0.82448 \\
0.89612\end{array}$ & 0.97065 & 0.97386 & 0.75653 \\
\hline $\begin{array}{l}\text { Social: Overall, I believe that this restaurant ... } \\
\text { SOC10: encourages employee participation in community projects. } \\
\text { SOC11: provides consumers with local food with high-quality service. } \\
\text { SOC12: stimulates the economic development in the community. } \\
\text { SOC13: donates foods to the community. } \\
\text { SOC2: employs local employees. } \\
\text { SOC3: ensures employee quality of life. } \\
\text { SOC4: provide a safe and healthy environment for consumers. } \\
\text { SOC5: contracts suppliers who are sustainable and green partners. } \\
\text { SOC6: operates legally and ethically. } \\
\text { SOC7: brings social responsibility into the food supply chain management. } \\
\text { SOC8: ensures employee quality of life. } \\
\text { SOC9: provides all consumers with accurate and adequate information about food in } \\
\text { making purchasing decisions. } \\
\text { SOC10: uses locally sourced foods from local suppliers. }\end{array}$ & $\begin{array}{l}0.90807 \\
0.91567 \\
0.89329 \\
0.78564 \\
0.92709 \\
0.88312 \\
0.90871 \\
0.85796 \\
0.86998 \\
0.92640 \\
0.89985 \\
0.90779 \\
0.93009\end{array}$ & 0.97892 & 0.98104 & 0.79949 \\
\hline $\begin{array}{l}\text { Economic: Overall, I believe that this restaurant has ... } \\
\text { ECO1: low operational cost } \\
\text { ECO2: high overall performance and success level } \\
\text { ECO3: high occupation rate growth } \\
\text { ECO4: high-profit growth } \\
\text { ECO5: high competitive position } \\
\text { ECO6: high return on their assets } \\
\text { ECO7: high rate of new food items introduction to market } \\
\text { ECO8: high advertising and marketing intensity }\end{array}$ & $\begin{array}{l}0.91424 \\
0.90208 \\
0.88903 \\
0.91606 \\
0.90473 \\
0.85650 \\
0.89608 \\
0.86587\end{array}$ & 0.9637 & 0.96931 & 0.79800 \\
\hline $\begin{array}{l}\text { Emotional } \\
\text { EMO1: makes me feel happy. } \\
\text { EMO2: gives me pleasure. } \\
\text { EMO3: changes my mood positively. } \\
\text { EMO4: fascinates me. } \\
\text { EMO5: makes me crave it. } \\
\text { EMO6: makes me feel excited (removed due to multicollinearity) }\end{array}$ & $\begin{array}{l}0.94443 \\
0.92329 \\
0.90980 \\
0.92714 \\
0.93689\end{array}$ & 0.96945 & 0.97520 & 0.86766 \\
\hline $\begin{array}{l}\text { Epistemic } \\
\text { EPS1: I want to seek out more information about sustainable local food. } \\
\text { EPS2: I am more curious about sustainable local food. } \\
\text { EPS3: eating sustainable local food is a good opportunity for me to learn new things. } \\
\text { EPS4: want to try more diverse sustainable local food. } \\
\text { EPS5: my knowledge of sustainable local food has increased. } \\
\text { EPS6: I learn dining habits through my food experiences (e.g., how to eat the food, } \\
\text { how to use utensils). }\end{array}$ & $\begin{array}{l}0.91018 \\
0.90950 \\
0.87112 \\
0.90337 \\
0.90135 \\
0.87437\end{array}$ & 0.95033 & 0.96029 & 0.80125 \\
\hline
\end{tabular}


Table 3. Cont.

\begin{tabular}{|c|c|c|c|c|}
\hline Construct/Item & $\begin{array}{c}\text { Item } \\
\text { Loadings }\end{array}$ & $\begin{array}{c}\text { Cronbach's } \\
\text { Alpha }\end{array}$ & CR & (AVE) \\
\hline $\begin{array}{l}\text { Health: Sustainable local food ... } \\
\text { HLT1: is hygienic. } \\
\text { HLT2: makes me healthy. } \\
\text { HLT3: is safe. } \\
\text { HLT4: provides good nutrition. }\end{array}$ & $\begin{array}{l}0.94365 \\
0.92635 \\
0.94315 \\
0.92661\end{array}$ & 0.95200 & 0.96527 & 0.87419 \\
\hline $\begin{array}{l}\text { Interaction } \\
\text { INTR1: My friendship with my travel companion has increased while eating } \\
\text { sustainable local food together. } \\
\text { INTR2: Eating sustainable local food helps me interact with the people I travel with. }\end{array}$ & $\begin{array}{l}0.88731 \\
0.93629\end{array}$ & 0.80153 & 0.90822 & 0.83197 \\
\hline $\begin{array}{l}\text { Price: Sustainable local food } \\
\text { PRC1: is reasonably priced. } \\
\text { PRC2: Offers value for money. }\end{array}$ & $\begin{array}{l}0.92732 \\
0.91219\end{array}$ & 0.81834 & 0.91657 & 0.84601 \\
\hline $\begin{array}{l}\text { Prestige } \\
\text { PRE1: Eating sustainable local food gives me a chance to show off my sustainable } \\
\text { local food experiences to others. } \\
\text { PRE2: I have higher social status when eating well-known sustainable local food. } \\
\text { PRE3: It is worthwhile to show pictures of my sustainable local food experiences to } \\
\text { others. } \\
\text { PRE4: Eating well-known sustainable local food gives me prestige. }\end{array}$ & $\begin{array}{l}0.90301 \\
0.91217 \\
0.92278 \\
0.89208\end{array}$ & 0.92867 & 0.94920 & 0.82370 \\
\hline $\begin{array}{l}\text { Quality: Sustainable local food } \\
\text { TQ1: provides a variety of ingredients. } \\
\text { TQ2: provides good quality ingredients. } \\
\text { TQ3: provides appealing flavors. } \\
\text { TQ4: is tasty. } \\
\text { TQ5: has a high standard of quality. }\end{array}$ & $\begin{array}{l}0.88411 \\
0.80747 \\
0.80243 \\
0.81965 \\
0.82958\end{array}$ & 0.88637 & 0.91658 & 0.68751 \\
\hline $\begin{array}{l}\text { Destination Branding } \\
\text { DB1: The USA provides delicious food. } \\
\text { DB2: The USA provides diverse food. } \\
\text { DB3: The USA provides rich food culture. } \\
\text { DB4: The USA provides traditional food culture. } \\
\text { DB5: The USA provides unique food. }\end{array}$ & $\begin{array}{l}0.73066 \\
0.78098 \\
0.83847 \\
0.77626 \\
0.71460\end{array}$ & 0.82649 & 0.87853 & 0.59201 \\
\hline
\end{tabular}

Table 4. Heterotrait-Monotrait Ratio (HTMT).

\begin{tabular}{|c|c|c|c|c|c|c|c|c|c|c|}
\hline & Branding Destination & Emotional & Environmental & Health & Social & Economic & Epistemic & Interaction & Prestige & Price \\
\hline Emotional & 0.57815 & & & & & & & & & \\
\hline Environmental & 0.68053 & 0.51096 & & & & & & & & \\
\hline Health & 0.64964 & 0.70121 & 0.52794 & & & & & & & \\
\hline Social & 0.52084 & 0.44173 & 0.43984 & 0.54192 & & & & & & \\
\hline Economic & 0.43125 & 0.67026 & 0.37286 & 0.49740 & 0.27600 & & & & & \\
\hline Epistemic & 0.54822 & 0.52657 & 0.44266 & 0.52098 & 0.51784 & 0.30516 & & & & \\
\hline Interaction & 0.50225 & 0.52316 & 0.35459 & 0.64698 & 0.42379 & 0.52099 & 0.55144 & & & \\
\hline Prestige & 0.46614 & 0.55298 & 0.36140 & 0.60584 & 0.44575 & 0.55259 & 0.55040 & 0.78812 & & \\
\hline Price & 0.29679 & 0.34929 & 0.30143 & 0.30388 & 0.19891 & 0.35408 & 0.16440 & 0.29645 & 0.32071 & \\
\hline Quality & 0.43016 & 0.52811 & 0.41107 & 0.38679 & 0.42375 & 0.37090 & 0.42948 & 0.34014 & 0.41220 & 0.18610 \\
\hline
\end{tabular}

\section{Results}

When evaluating the structural model, two main criteria were used, R2 and the significance of the path coefficient [90]. The estimated results are shown in Figure 2, which confirmed that the composite path coefficients are statistically significant. $R^{2}$ values, range between $82 \%$ and $98 \%$, indicating a substantial explanatory power as shown in Figure 3 [91]. The results showed that:

First, the environmental dimension of SLFSC had positive effects on the tourists' emotional $(\beta=0.227, p=0.007))$, epistemic $(\beta=0.227, p=0.026)$, health $(\beta=0.260, p=0.004)$, and taste and quality $(\beta=0.20, p=0.001)$ values. Additionally, it had no effect on price $(\beta=0.153, p<0.07)$, interaction $(\beta=0.081, p=0.269)$, and prestige $(\beta=0.073, p=0.26)$ values of the tourists. Hence, these results supported H1.1, H1.2, H1.3, and H1.5 and did not support H1.4, H1.6, and H1.7 (see Table 5). 


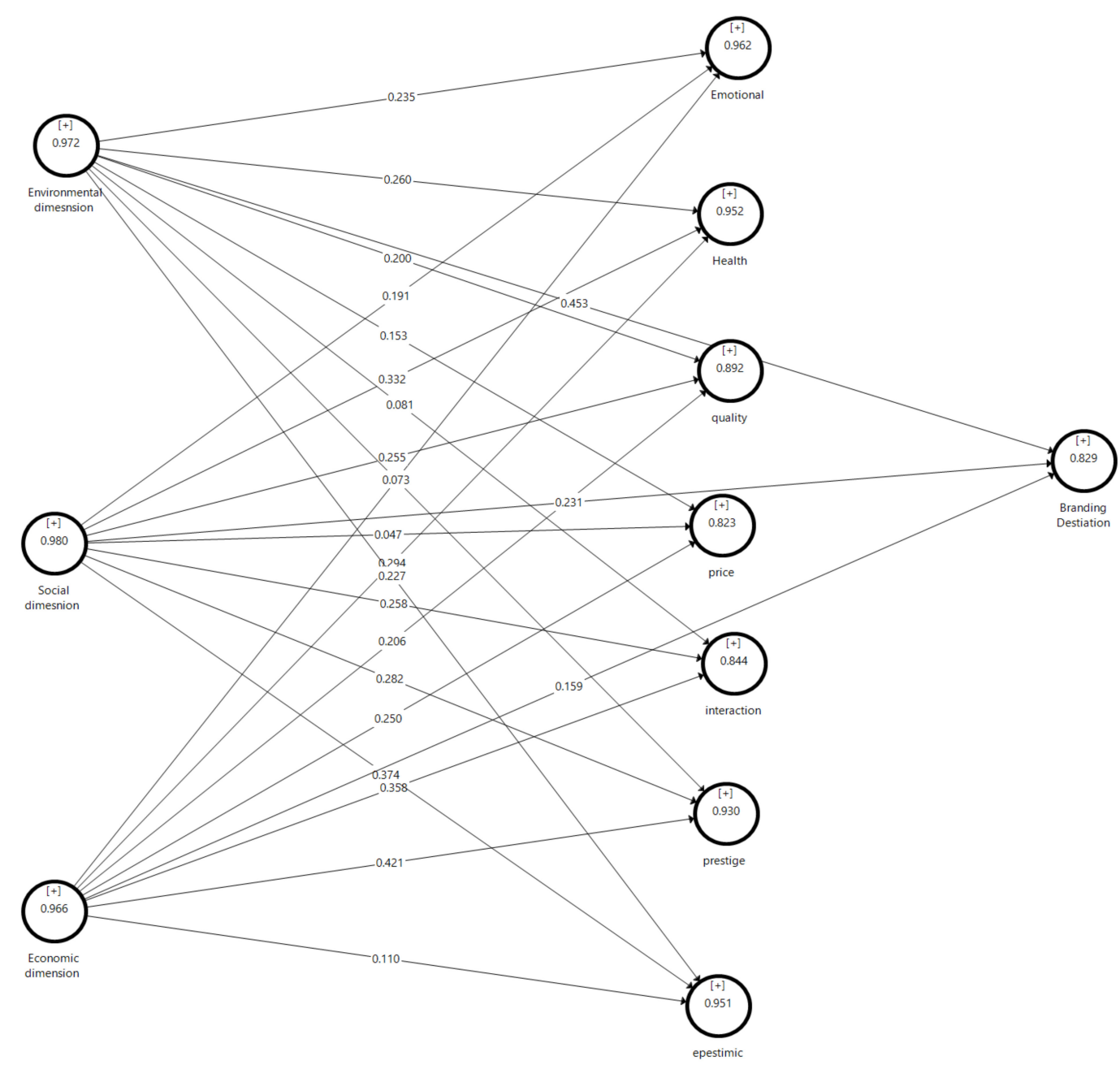

Figure 2. Path coefficients and $\mathrm{R}^{2}$.

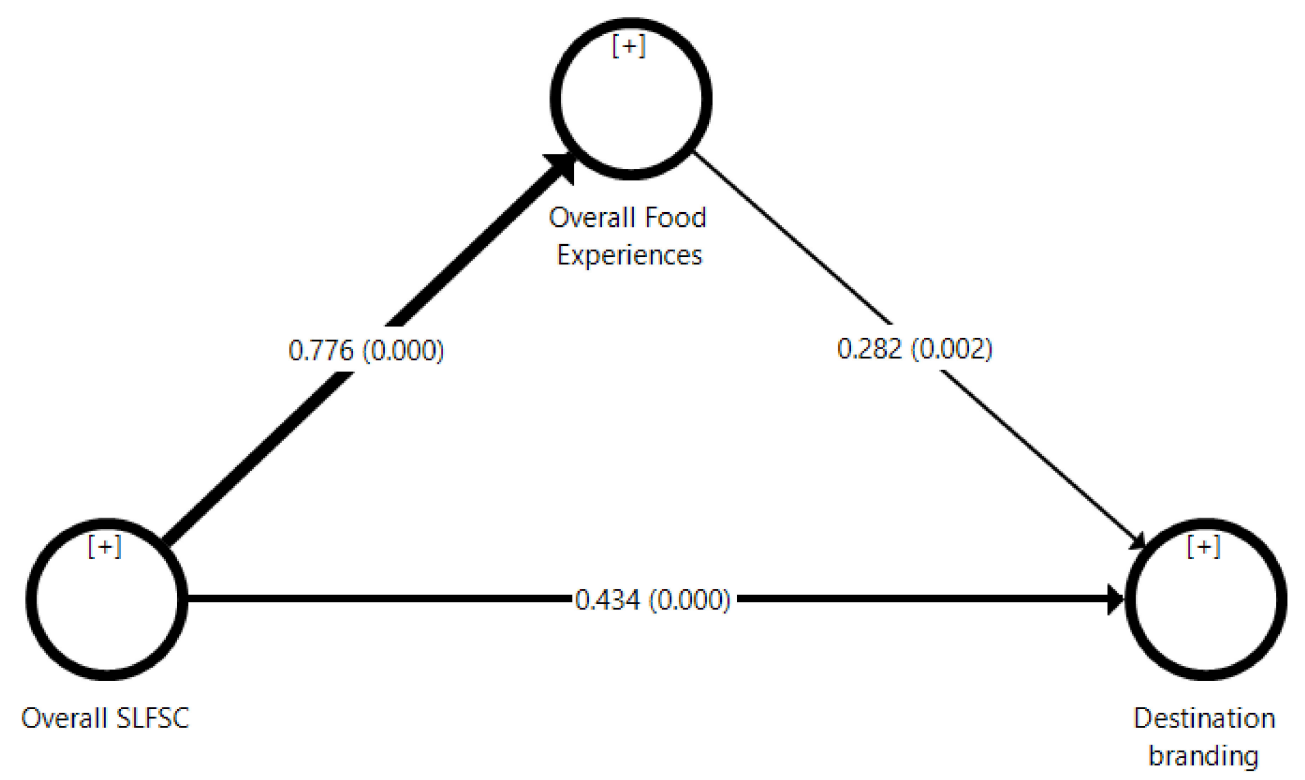

Figure 3. The path coefficient and $p$ values. 
Table 5. Summary of the hypotheses-testing results.

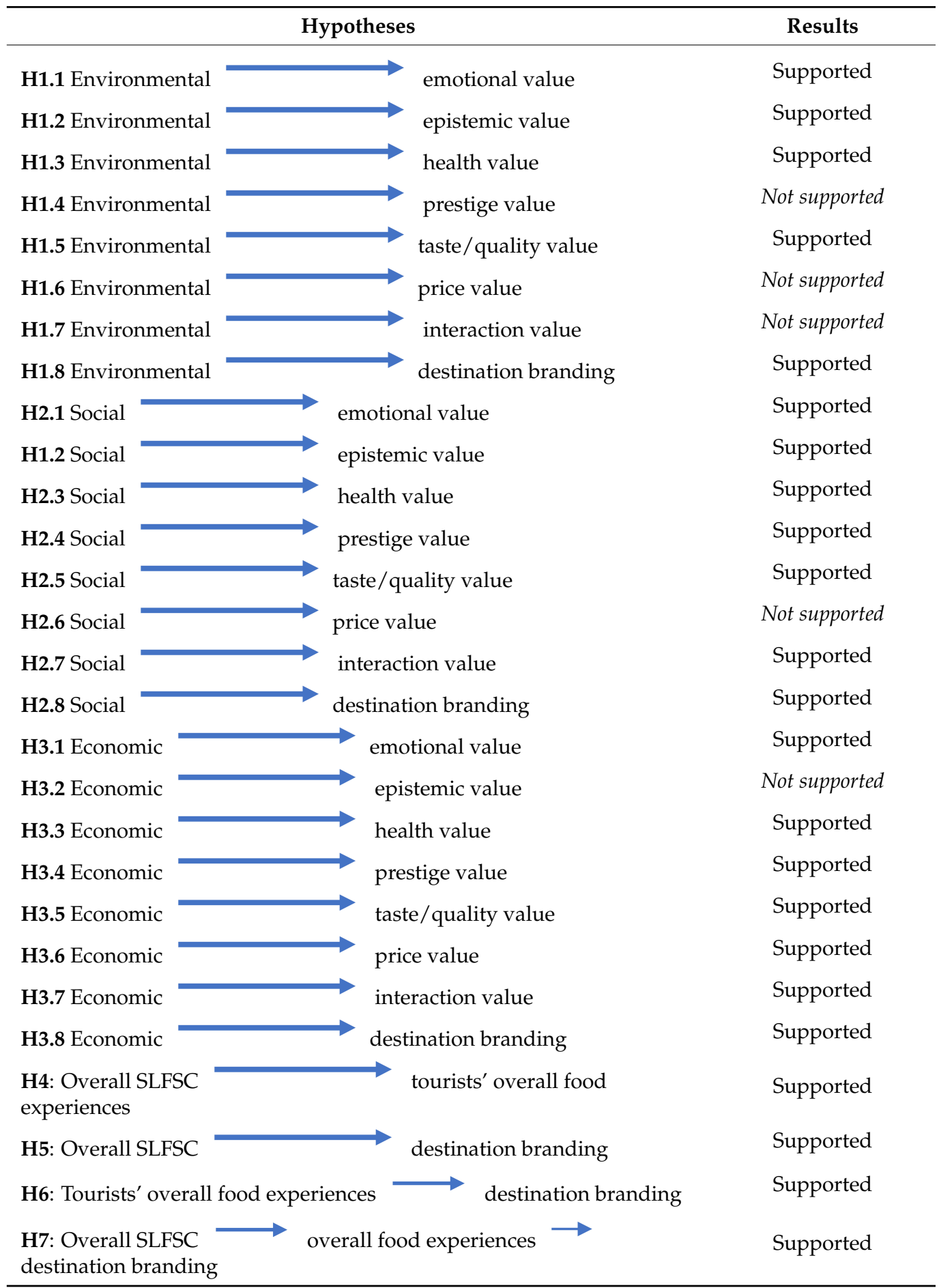

Second, the social dimension of SLFSC had positive effects on the tourists' epistemic $(\beta=0.374, p=0.000)$, health $(\beta=0.332, p=0.000)$, prestige $(\beta=0.0 .282, p=0.000)$, interaction $(\beta=0.258, p=0.005)$, taste/quality $(\beta=0.255, p=0.008)$, and emotional ( $\beta=0.194, p=0.039)$ values, and there was no effect on the price value $(\beta=0.047, p=0.635)$. Hence, these results supported $\mathrm{H} 2.2, \mathrm{H} 2.3, \mathrm{H} 2.4, \mathrm{H} 2.7$, H2.5, and H2.1, while $\mathrm{H} 2.6$ was not supported (see Table 5).

Third, the economic dimension of SLFSC had positive effects on the tourists' emotional $(\beta=0.515, p=0.0000)$, prestige $(\beta=0.421, p=0.000)$, interaction $(\beta=0.358, p=0.000)$, health $(\beta=0.294, p=0.001)$, price $(\beta=0.250, p=0.010)$, and taste and quality $(\beta=0.206$, 
$p=0.016)$ values, whilst there was no effect on the epistemic value $(\beta=0.110, p=0.238)$. Hence, these results supported H3.1, H3.4, H3.7, H3.3, H3.6, and H3.5, while H3.2 was not supported (see Table 5).

Finally, the findings clearly demonstrated that all dimensions of SLFSC, environmental, social, and economic, were found to have strong positive effects on the destination branding $(\beta=0.453, p=0.000),(\beta=0.231, p=0.0003)$, and $(\beta=0.159, p=0.028)$, respectively. Therefore, H1.8, H2.8, and H3.8 were supported. Additionally, the overall sustainability of LFSC in the green fine-dining restaurants had strong positive correlations with the overall food experience of tourists $(\beta=0.776, p=0.000)$ and destination branding $(\beta=0.434$, $p=0.000$ ). This supported H4 and H5, respectively, as shown in Table 5. Similarly, the overall tourist food experiences were found to have positive effects on destination branding ( $\beta=0.282, p=0.004$ ) and mediate the relationship between the overall sustainability of LFSC and destination branding $(\beta=0.219)$. Thus, hypotheses $\mathrm{H} 6$ and $\mathrm{H} 7$ were supported, as presented in Figure 3.

\section{Discussion and Conclusions}

In general, the sustainability of supply chain management could generate strategic and operational advantages that enable organizations to fulfill their responsibilities to the environment, society, and stakeholders [95].This study empirically investigated the influences of SLFSC on tourist food experiences and destination branding as perceived by tourist patrons of the green fine-dining restaurant in the USA. Hence, this study depended on the path coefficients of the research variables, which were extracted from the outcomes of SmartPLS-SEM software, to explore these relationships. Overall, the findings of this study showed that all SLFSCs' dimensions were positively correlated to the majority of tourist consumption values and destination branding.

Interestingly, all sustainability dimensions of LFSC have positive relations with the emotional values of patrons which supports the findings of $[55,96]$ whose corroborated that tourists gain pleasure, excitement, and relaxation by eating local dishes at a tourist destination. Hence, the high-quality advertisements for sustainable local food would entice positive emotional appeal to tourists. Consequently, the two-way relationship between the environment and tourists provides an opportunity for sustainable fine-dining restaurants, during and beyond COVID-19, to ascertain the emotional value that can be had from the meals. Restaurant-industry playmakers would introduce local food as excitement and relaxation to entice new customers.

The results found positive effects of all the sustainability dimensions, environmental, social, and economic, of local food on tourists' health and taste/quality value. These results are consistent with Guptill and Wilkins [97] whose demonstrated that purchasing sustainable local products within the FSC fosters health, food security, and well-being of people. This finding confirmed that patrons of fine-dining restaurants are becoming aware of the nutrition ingredients and food safety and risks to health. Providing local food with environmental, social and economic concerns increases personal gratification for tourists regarding the environmental ingredients, nutrition information, food handling procedures, usage of local agricultural supplies and supporting local farmers. This could lead to enhance the community's social relations and social justice for locals. Additionally, Kim et al. [63] stated that the taste and quality of food is a trigger for tourists to experience local food. Tourists are leveraging food sustainability to improve the freshness and quality of the meal by significantly shorting the FSC cycle time. Moreover, the participants stressed that green fine-dining restaurants care about product quality and enhance added value for local food. This, in turn, leads to raise the welfare of the local community and achieve a competitive edge for green restaurants during and beyond Covid 19 pandemic.

Surprisingly, only the economic dimension of SLFSC was found to have a positive relationship with the price value of tourists. The participants believed that having a healthy meal from local ingredients considering food sustainability burdens could be costly for both consumers and restaurants. Hence, patrons have to pay a premium to compensate sus- 
tainability costs of production, processing, and distribution of local foods [30,31]. However, despite the penalty of compensating costs of sustainable local meals, tourists' budgets and welfare were not affected. Thus, tourist expectations of meal prices and value for money in a sustainable manner were met. Also, green fine-dining restaurants are a top-ranked category with high investments leading to high-end customer satisfaction. Consequently, the more investments in sustainable restaurants, the higher the price of meals will be. This finding demonstrated the desire of the participants to support the economy of the local community during this pandemic. Conversely, the non-significance correlation of the environmental dimension may be due to other costs related to SLFC practices which are considered more expensive than the meal ingredients themselves. Regarding the social context, due to the low number of green fine-dining restaurants (19 restaurants) in the U.S.A, participants got bored of repeated menus. Restaurateurs should exploit the benefits of the COVID-19 outbreak that forced customers to change their food habits and consumption values to sustainable local foods. Thus, there is a need to increase the number of green fine-dining restaurants and develop new menus regularly with a wide variety of dishes to attract more tourists. Furthermore, new marketing techniques should be employed to target those patrons.

Except for the economic dimension, the epistemic value of tourists was found to have a positive correlation with the environmental and social dimensions of SLFSC. These results are consistent with the previous research of $[27,63]$ whose argued that tourists could obtain knowledge and experience of a local people's culture when consuming local food. Additionally, tourists believed that sustainably consuming local food is a primary ethic toward the environment and society more than having prestige among others as a sort of distinction. Accordingly, this may explain the insignificance of the economic dimension. Interaction and prestige values were positively correlated only with the social and environmental dimensions of SLFSC. The "interaction value" and "prestige value" Fields were conceptualized as belonging to social values $[61,63]$, which supports the research findings. Additionally, participants feel enjoyment, fun, and prestige while dining together with family, friends, etc. in these green fine-dining restaurants.

Moreover, the overall sustainability of LFSC, all three dimensions together, had strong positive effects on the tourists' overall food experiences. This result is concurring with the finding of [86] whose confirmed that the dimensions of sustainability of FSC management in the hotel establishments in south Sardinia, Italy, were found to positively affect tourists' attitudes and behaviors. Furthermore, Choe and Kim [27] found a significant positive relationship between local food and tourist food consumption values. Thus, producing and presenting locally sourced meals in sustainable ways is crucial for tourists' food consumption experience. This finding shows that tourists perceive sustainable food as having better quality and higher value than other types of comparable food. Consequently, SLFC is a tool for green restaurants questing for a "peak tourist experience", thereby, attracting high volumes of tourists and achieving both restaurants' competencies (i.e., financial resources, technical knowledge, reputation ... etc.) and competitive edge during and beyond the COVID 19 pandemic. Restaurants should be transparent in marketing the actual SLFSC practices to avoid greenwashing claims. Thus, restaurateurs should be honest and fair to their customers by the disclosure of both sustainable and non-sustainable practices of the restaurant FSC. Thus, restaurants that seek to be featured sustainable in the FSC should be verified and accreted by a credible association or authority.

The findings of this study indicated that each sustainability dimension and overall sustainability of LFSC had strong positive effects on destination branding. Furthermore, the environmental dimension of SLFC had the steepest positive impacts on branding the destination followed by the social dimension, whereas the economic dimension had the least effects. This finding is consistent with previous studies that focused on eco-sustainability [98] and the social development of the local community [99,100]. Modica et al. [86] mentioned that socially responsible activities of restaurants such as the choice of environmental-friendly suppliers and the cooperation with nearby and local suppliers contributed to the brand 
image. The more the consumption of LFSC in a sustainable manner, the more effective marketing and branding the destination. Thus, if promoted and marketed effectively in the place, SLFC will enhance the destination's attractiveness and its image distinctiveness. This finding is supported by Alderighi et al. [101] whose found that local foods had a market-expanding role in destination branding and a strong appreciation for local food positively affected the revisit intention to the destination.

Finally, tourist food experiences in totality mediated the relationship between the overall SLFSC and destination branding. The finding revealed an indirect positive relationship between the overall sustainability of LFSC and branding a destination. Thus, to brand a destination through SLFSC, restaurant operators and authorities should pay more attention to the tourist food experiences. This positive linkage between the overall sustainability of LFC and tourists' overall food experiences represents an essential pillar of branding and marketing of the destination [81]. Thus, satisfying the overall needs of tourists (i.e., SLFC and food consumption experiences) in different hospitality establishments or/and food outlets helps create positive motives toward the destination image perception which in turn leads to the sustainable development of that destination.

\section{Implications}

This study enriches the literature with an applied framework to promote four research disciplines: sustainability, LFSC, food customer experiences, and destination branding. Due to intensive arguments regarding the importance of aligning the FSC in the hospitality and restaurant industry to sustainability principles, this research paper is considered a pioneer study that aligned and investigated the sustainability of LFSC in the restaurant industry. Previous studies have focused on explaining and examining the influence of a single aspect of sustainability and other variables. The current study investigated the three dimensions of SLFSC and the SLFC in totality. This study contributes to the existing literature by developing and validating a scale to measure the sustainability practices of LFSC in restaurants to fill this gap in the literature. As the scale was sufficient and effective at measuring the sustainability practices of LFSC, consequently, the scale can be used for future research in hospitality. However, most of the previous studies used the terms locality and sustainability of food interchangeably. A crucial implication of this research study is the differentiation between locality and sustainability of food. This study provided academia with a comprehensive review of the prior research studies on LFSC and a comprehensive explanation of the sustainability of LFSC.

For practice, this study reveals empirical findings of actual sustainable green finedining restaurants. Thus, due to the COVID 19 outbreak that forced restaurants to featured local food ingredients, restaurants that are willing and ready to be sustainable green restaurants to survive could use the practices of these green fine-dining restaurants as a guide and reference. The results of the study showed the importance of studying the three dimensions of sustainability not just focusing on one dimension. Consequently, this study showed a positive effect of all sustainability dimensions on most consumption values of tourists. Thus, the influences of every dimension of sustainability should be considered explicitly and implicitly when the marketing strategies of SLFSC are designed for restaurants during the COVID 19 pandemic.

The finding of this research study found significant positive relationships between all sustainability dimensions of LFSC and tourist consumption values of emotional, health, and taste/quality. It is notable that participants of the study are more aware of the sustainability practices of LSFC in these restaurants and decide/prefer to dine in. In this regard, it can be stated that as tourist demand for these items grows, restaurants will become more inclined to serve them, resulting in increased sustainable local food consumption. Thus, relevant authorities can conduct research and launch national initiates to raise awareness and encourage the use of sustainable local foods in restaurants' supply chain management. Such initiatives have been launched before by local food associations to conserve both the local and global environment through working to promote the consumption movement 
of locally sourced foods and to support sustainable food production methods. Therefore, restaurants will be forced to source sustainable local foods in their FSC to meet the customer needs. The results confirmed a positive relationship between all the sustainability dimensions, environmental, social, and economic, and tourists' health and taste/quality values. Thus, restaurant operators should pay more attention to the freshness and quality of the ingredients and cooking methods to be able to improve life and societal wellbeing. Additionally, adapting an open kitchen policy in restaurants leads to building a strong relationship between tourists and restaurants as long as restaurants maintain their standards with their sustainability practices. Additionally, policymakers should provide incentives to farmers, retailers, and restaurants that adopt or intend to adopt SLFSC such as tax reduction to overcome over costs related to the FSC itself. Conversely, authorities should take deterrent measures against greenwashing practices of restaurants regarding SLFSC. Environmental and social dimensions were positively correlated with the interaction and prestige values of tourists. Hence, more attention must be paid when using prestige and interaction as marketing tools due to the differentiation of the cultural background of tourists.

The findings indicated that each sustainability dimension and overall sustainability of LFSC had strong positive effects on destination branding. Additionally, tourist food experiences in totality mediated the relationship between the overall SLFSC and destination branding. This indicates the uniqueness of sustainability of local foods to promote both tourist food experiences and destination branding. Sustainable local food conveyed a sense of authenticity and uniqueness and reinforce the external image of the destination. Thus, for policymakers, is important to encourage various enablers for sustainability practices in the LFSCs. Thus, they should focus on the SLFSC and tourist food experiences as effective tools for promoting and marketing to a destination. This leads to brand the destination and attract more tourists which, in turn, boosts the environmental, social, and economic social development.

\section{Limitation of the Study and Future Research}

The present study presents potential limitations that should be taken into account in future research. First, sampling is not randomized to cover all types of green restaurants, which limits generalizability to the larger restaurant industry. Further research would replicate this research study with more diverse samples to enhance generalizability in different geographical regions. Second, due to the double test of the shortened scale of SLFSC, the refinement version may be imperfect. More future research is required to test the consistency of the scale in different disciplines. Third, this study measured the sustainability of LFSC from customers' perspectives. Further research could replicate the study from a restaurant operator's point of view. Finally, this study investigated tourist experiences in terms of consumption values, and future research may focus on multi-dimensional motives in a nationwide perspective to collect more accurate results.

Author Contributions: Conceptualization, O.A. and B.A.; methodology, O.A., M.A.-K. and B.A.; software, O.A.; validation, M.A.-K., B.A. and O.A.; formal analysis, O.A.; investigation, O.A. and M.A.-K.; resources, O.A.; data curation, O.A. and M.A.-K.; writing-original draft preparation, O.A., M.A.-K. and B.A.; writing-review and editing O.A., M.A.-K. and B.A.; visualization, O.A., M.A.-K. and B.A.; supervision, O.A., M.A.-K. and B.A.; project administration, O.A., B.A. and M.A.-K. All authors have read and agreed to the published version of the manuscript.

Funding: This research was funded by the Ministry of Higher Education, Egypt.

Institutional Review Board Statement: Not applicable.

Informed Consent Statement: Not applicable.

Data Availability Statement: Not available.

Acknowledgments: We thank our families' support and the participants of the study. 
Conflicts of Interest: The authors declare no conflict of interest.

\section{References}

1. American Hotel Association (AHLA). State of the Hotel Industry Analysis: Covid-19 Six Months Later; American Hotel Association: Chicago, IL, USA, 2020.

2. UNWTO. COVID-19 Related Travel Restrictions-A Global Review for Tourism; UNWTO: Madrid, Spain, 2020.

3. National Restaurant Association (NRA). State of the Restaurant Industry; National Restaurant Association: Washington, DC, USA, 2019.

4. Wendy's Customers Ask "Where's the Beef?" as Restaurants Remove Menu Items | Fox Business. Available online: https: //www.foxbusiness.com/lifestyle/wendys-meat-shortage-menu-items-removed (accessed on 12 August 2021).

5. Eating Out after COVID: Some Consumer Trends Are Already Emerging-FoodTec Solutions. Available online: https:// foodtecsolutions.com/blog/2020/08/21/eating-out-after-covid-some-consumer-trends-are-already-emerging/ (accessed on 12 August 2021).

6. Bryła, P. Regional Ethnocentrism on the Food Market as a Pattern of Sustainable Consumption. Sustainability 2019, 11, 6408. [CrossRef]

7. Beske, P.; Land, A.; Seuring, S. Sustainable Supply Chain Management Practices and Dynamic Capabilities in the Food Industry: A Critical Analysis of the Literature. Int. J. Prod. Econ. 2014, 152, 131-143. [CrossRef]

8. Lang, M.; Lemmerer, A. How and Why Restaurant Patrons Value Locally Sourced Foods and Ingredients. Int. J. Hosp. Manag. 2019, 77, 76-88. [CrossRef]

9. Campbell, J.; DiPietro, R.B.; Remar, D. Local Foods in a University Setting: Price Consciousness, Product Involvement, Price/Quality Inference and Consumer's Willingness-to-Pay. Int. J. Hosp. Manag. 2014, 42, 39-49. [CrossRef]

10. Zhang, T.; Grunert, K.G.; Zhou, Y. A Values-Beliefs-Attitude Model of Local Food Consumption: An Empirical Study in China and Denmark. Food Qual. Prefer. 2020, 83, 103916. [CrossRef]

11. Schmitt, E.; Galli, F.; Menozzi, D.; Maye, D.; Touzard, J.M.; Marescotti, A.; Six, J.; Brunori, G. Comparing the Sustainability of Local and Global Food Products in Europe. J. Clean. Prod. 2017, 165, 346-359. [CrossRef]

12. Björk, P.; Kauppinen-Räisänen, H. Local Food: A Source for Destination Attraction. Int. J. Contemp. Hosp. Manag. 2016, 28, 177-194. [CrossRef]

13. Aaltojärvi, I.; Kontukoski, M.; Hopia, A. Framing the Local Food Experience: A Case Study of a Finnish Pop-up Restaurant. Br. Food J. 2018, 120, 133-145. [CrossRef]

14. Restaurant Revolution: How The Industry Is Fighting To Stay Alive. Available online: https://www.forbes.com/sites/ hbsworkingknowledge/2020/08/10/restaurant-revolution-how-the-industry-is-fighting-to-stay-alive/?sh=211593d1f1eb (accessed on 12 August 2021).

15. Shin, Y.H.; Im, J.; Jung, S.E.; Severt, K. Consumers' Willingness to Patronize Locally Sourced Restaurants: The Impact of Environmental Concern, Environmental Knowledge, and Ecological Behavior. J. Hosp. Mark. Manag. 2017, 26, 644-658. [CrossRef]

16. Xu, X.; Gursoy, D. Influence of Sustainable Hospitality Supply Chain Management on Customers' Attitudes and Behaviors. Int. J. Hosp. Manag. 2015, 49, 105-116. [CrossRef]

17. Szuchnicki, A.L. Examining the Influence of Restaurant Green Practices on Customer Return Intention Customer Return Intention. Master's Thesis, University of Nevada, Las Vegas, NV, USA, December 2009. [CrossRef]

18. DuPuis, E.M.; Goodman, D. Should We Go "Home" to Eat?: Toward a Reflexive Politics of Localism. J. Rural. Stud. 2005, 21, 359-371. [CrossRef]

19. Roy, H.; Hall, C.M.; Ballantine, P.W. Trust in Local Food Networks: The Role of Trust among Tourism Stakeholders and Their Impacts in Purchasing Decisions. J. Destin. Mark. Manag. 2017, 6, 309-317. [CrossRef]

20. Gössling, S.; Hall, C.M. Sustainable Culinary Systems: An Introduction. In Sustainable Culinary Systems: Local Foods, Innovation, Tourism and Hospitality; Routledge: Oxfordshire, UK, 2013. [CrossRef]

21. Edwards-Jones, G.; Milà i Canals, L.; Hounsome, N.; Truninger, M.; Koerber, G.; Hounsome, B.; Cross, P.; York, E.H.; Hospido, A.; Plassmann, K.; et al. Testing the Assertion That 'Local Food Is Best': The Challenges of an Evidence-Based Approach. Trends Food Sci. Technol. 2008, 19, 265-274. [CrossRef]

22. McWilliams, J.E. Just Food: Where Locavores Get It Wrong and How We Can Truly Eat Responsibly; Little, Brown and Company: Boston, MA, USA, 2009; p. 258.

23. Coelho, F.C.; Coelho, E.M.; Egerer, M. Local Food: Benefits and Failings Due to Modern Agriculture. Sci. Agric. 2018, 75, 84-94. [CrossRef]

24. Hanks, L.; Mattila, A.S. Consumer Response to Organic Food in Restaurants: A Serial Mediation Analysis. J. Foodserv. Bus. Res. 2016, 19, 109-121. [CrossRef]

25. Matson-Barkat, S.; Robert-Demontrond, P. Who's on the Tourists' Menu? Exploring the Social Significance of Restaurant Experiences for Tourists. Tour. Manag. 2018, 69, 566-578. [CrossRef]

26. Morgan, M. Making Space for Experiences. J. Retail. Leis. Prop. 2006, 5, 305-313. [CrossRef]

27. Choe, J.Y.; Kim, S. Development and Validation of a Multidimensional Tourist's Local Food Consumption Value (TLFCV) Scale. Int. J. Hosp. Manag. 2019, 77, 245-259. [CrossRef] 
28. Björk, P.; Kauppinen-Räisänen, H. Culinary-Gastronomic Tourism-A Search for Local Food Experiences. Nutr. Food Sci. 2014, 44, 294-309. [CrossRef]

29. Johnson, R. The Role of Local and Regional Food Systems in U.S. Farm Policy; Congressional Research Service: Washington, DC, USA, 2016; pp. 1-41.

30. Frash, R.E.; DiPietro, R.; Smith, W. Pay More for McLocal? Examining Motivators for Willingness to Pay for Local Food in a Chain Restaurant Setting. J. Hosp. Mark. Manag. 2015, 24, 411-434. [CrossRef]

31. Brunori, G.; Galli, F.; Barjolle, D.; van Broekhuizen, R.; Colombo, L.; Giampietro, M.; Kirwan, J.; Lang, T.; Mathijs, E.; Maye, D.; et al. Are Local Food Chains More Sustainable than Global Food Chains? Considerations for Assessment. Sustainability 2016, 8 , 449. [CrossRef]

32. Holmes, M.R.; Dodds, R.; Deen, G.; Lubana, A.; Munson, J.; Quigley, S. Local and Organic Food on Wheels: Exploring the Use of Local and Organic Food in the Food Truck Industry. J. Foodserv. Bus. Res. 2018, 21, 493-510. [CrossRef]

33. DiPietro, R.B.; Gregory, S.; Jackson, A. Going Green in Quick-Service Restaurants: Customer Perceptions and Intentions. Int. J. Hosp. Tour. Adm. 2013, 14, 139-156. [CrossRef]

34. Sharma, A.; Gregoire, M.B.; Strohbehn, C. Assessing Costs of Using Local Foods in Independent Restaurants. J. Foodserv. Bus. Res. 2009, 12, 55-71. [CrossRef]

35. Sharma, A.; Moon, J.; Strohbehn, C. Restaurant's Decision to Purchase Local Foods: Influence of Value Chain Activities. Int. J. Hosp. Manag. 2014, 39, 130-143. [CrossRef]

36. Inwood, S.M.; Sharp, J.S.; Moore, R.H.; Stinner, D.H. Restaurants, Chefs and Local Foods: Insights Drawn from Application of a Diffusion of Innovation Framework. Agric. Hum. Values 2009, 26, 177-191. [CrossRef]

37. Ashby, A.; Leat, M.; Hudson-Smith, M. Making Connections: A Review of Supply Chain Management and Sustainability Literature. Supply Chain. Manag. 2012, 17, 497-516. [CrossRef]

38. Benis, K.; Ferrão, P. Potential Mitigation of the Environmental Impacts of Food Systems through Urban and Peri-Urban Agriculture (UPA)—A Life Cycle Assessment Approach. J. Clean. Prod. 2017, 140, 784-795. [CrossRef]

39. Wu, P.J.; Huang, P.C. Business Analytics for Systematically Investigating Sustainable Food Supply Chains. J. Clean. Prod. 2018, 203, 968-976. [CrossRef]

40. Kang, K.H.; Stein, L.; Heo, C.Y.; Lee, S. Consumers' Willingness to Pay for Green Initiatives of the Hotel Industry. Int. J. Hosp. Manag. 2012, 31, 564-572. [CrossRef]

41. Kim, Y.J.; Kim, W.G.; Choi, H.M.; Phetvaroon, K. The Effect of Green Human Resource Management on Hotel Employees' Eco-Friendly Behavior and Environmental Performance. Int. J. Hosp. Manag. 2019, 76, 83-93. [CrossRef]

42. Seuring, S.; Sarkis, J.; Müller, M.; Rao, P. Sustainability and Supply Chain Management-An Introduction to the Special Issue. J. Clean. Prod. 2008, 16, 1545-1551. [CrossRef]

43. Hong, J.; Zhang, Y.; Ding, M. Sustainable Supply Chain Management Practices, Supply Chain Dynamic Capabilities, and Enterprise Performance. J. Clean. Prod. 2018, 172, 3508-3519. [CrossRef]

44. Hanifan, G.L.; Sharma, A.E.; Mehta, P. Why Sustainable Supply Chain Is Good Business. SAGE J. 2012, 3, 1-7.

45. Brandenburg, M.; Govindan, K.; Sarkis, J.; Seuring, S. Quantitative Models for Sustainable Supply Chain Management: Developments and Directions. Eur. J. Oper. Res. 2014, 233, 299-312. [CrossRef]

46. Hall, C.M.; Gössling, S. Food Tourism and Regional Development: Networks, Products and Trajectories. In Food Tourism and Regional Development: Networks, Products and Trajectories; Routledge: Oxfordshire, UK, 2016.

47. Dougherty, M.; Brown, L.; Green, G.P. The Social Architecture of Local Food Tourism: Challenges and Opportunities for Community Economic Development. J. Rural. Soc. Sci. 2013, 28, 1.

48. Definition of a Sustainable Food System. Available online: https://www.calgary.ca/ca/city-manager/definition-of-a-sustainablefood-system.html (accessed on 12 August 2021).

49. Pearson, D.; Henryks, J.; Trott, A.; Jones, P.; Parker, G.; Dumaresq, D.; Dyball, R. Local Food: Understanding Consumer Motivations in Innovative Retail Formats. Br. Food J. 2011, 113, 886-899. [CrossRef]

50. Feldmann, C.; Hamm, U. Consumers' Perceptions and Preferences for Local Food: A Review. Food Qual. Prefer. 2015, 40, 152-164. [CrossRef]

51. Martinez, S.; Hand, M.; da Pra, M.; Pollack, S.; Ralston, K.; Smith, T.; Vogel, S.; Clark, S.; Lohr, L.; Low, S.; et al. Local Food Systems: Concepts, Impacts, and Issues. In Local Food Systems: Background and Issues; Nova Science Publishers: Hauppauge, NY, USA, 2010.

52. Roininen, K.; Arvola, A.; Lähteenmäki, L. Exploring Consumers' Perceptions of Local Food with Two Different Qualitative Techniques: Laddering and Word Association. Food Qual. Prefer. 2006, 17, 20-30. [CrossRef]

53. Sims, R. Food, Place and Authenticity: Local Food and the Sustainable Tourism Experience. J. Sustain. Tour. 2009, 17, 321-336. [CrossRef]

54. Gentile, C.; Spiller, N.; Noci, G. How to Sustain the Customer Experience: An Overview of Experience Components That Co-Create Value with the Customer. Eur. Manag. J. 2007, 25, 395-410. [CrossRef]

55. Kim, Y.G.; Eves, A.; Scarles, C. Empirical Verification of a Conceptual Model of Local Food Consumption at a Tourist Destination. Int. J. Hosp. Manag. 2013, 33, 484-489. [CrossRef]

56. Mkono, M.; Markwell, K.; Wilson, E. Applying Quan and Wang's Structural Model of the Tourist Experience: A Zimbabwean Netnography of Food Tourism. Tour. Manag. Perspect. 2013, 5, 68-74. [CrossRef] 
57. Hall, M.C.; Mitchell, R. Wine and Food Tourism. In Special Interest Tourism; Wiley: Hoboken, NJ, USA, 2001.

58. Sánchez-Fernández, R.; Iniesta-Bonillo, M.Á. The Concept of Perceived Value: A Systematic Review of the Research. Mark. Theory 2007, 7, 427-451. [CrossRef]

59. Sanchez-Cañizares, S.; Castillo-Canalejo, A.M. A Comparative Study of Tourist Attitudes towards Culinary Tourism in Spain and Slovenia. Br. Food J. 2015, 117, 2387-2411. [CrossRef]

60. Sweeney, J.C.; Soutar, G.N. Consumer Perceived Value: The Development of a Multiple Item Scale. J. Retail. 2001, 77, 203-220. [CrossRef]

61. Williams, P.; Soutar, G.N. Value, Satisfaction and Behavioral Intentions in an Adventure Tourism Context. Ann. Tour. Res. 2009, 36, 413-438. [CrossRef]

62. Hansen, K.V.; Jensen, Ø.; Gustafsson, I.B. The Meal Experiences of á La Carte Restaurant Customers. Scand. J. Hosp. Tour. 2005, 5, 135-151. [CrossRef]

63. Kim, Y.G.; Eves, A. Construction and Validation of a Scale to Measure Tourist Motivation to Consume Local Food. Tour. Manag. 2012, 33, 1458-1467. [CrossRef]

64. Mak, A.H.N.; Lumbers, M.; Eves, A. Globalisation and Food Consumption in Tourism. Ann. Tour. Res. 2012, 39, 171-196. [CrossRef]

65. Wijaya, S.; King, B.; Nguyen, T.H.; Morrison, A. International Visitor Dining Experiences: A Conceptual Framework. J. Hosp. Tour. Manag. 2013, 20, 34-42. [CrossRef]

66. Wijaya, S.; King, B.; Morrison, A.; Nguyen, T.H. Destination Encounters with Local Food: The Experience of International Visitors in Indonesia. Tour. Cult. Commun. 2017, 17, 79-91. [CrossRef]

67. Tse, P.; Crotts, J.C. Antecedents of Novelty Seeking: International Visitors' Propensity to Experiment across Hong Kong's Culinary Traditions. Tour. Manag. 2005, 26, 965-968. [CrossRef]

68. Fields, K. Demand for Gastronomy Product: Motivational Factors. In Tourism and Gastronomy; Hjalager, A., Richards, G., Eds.; Routledge: London, UK, 2002.

69. Kim, Y.G.; Eves, A.; Scarles, C. Building a Model of Local Food Consumption on Trips and Holidays: A Grounded Theory Approach. Int. J. Hosp. Manag. 2009, 28, 423-431. [CrossRef]

70. Hauser, M.; Nussbeck, F.W.; Jonas, K. The Impact of Food-Related Values on Food Purchase Behavior and the Mediating Role of Attitudes: A Swiss Study. Psychol. Mark. 2013, 30, 765-778. [CrossRef]

71. Contini, C.; Romano, C.; Boncinelli, F.; Scozzafava, G.; Casini, L. Does 'Local' Matter in Restaurant Choice? Results of a Discrete Choice Experiment Targeting German and Italian Consumers. Agric. Food Econ. 2017, 5, 1-15. [CrossRef]

72. Baloglu, S.; McCleary, K.W. A Model of Destination Image Formation. Ann. Tour. Res. 1999, 26, 868-897. [CrossRef]

73. Yang, F.X.; Wong, I.K.A.; Tan, X.S.; Wu, D.C.W. The Role of Food Festivals in Branding Culinary Destinations. Tour. Manag. Perspect. 2020, 34, 100671. [CrossRef]

74. Pike, S.; Ryan, C. Destination Positioning Analysis through a Comparison of Cognitive, Affective, and Conative Perceptions. J. Travel Res. 2004, 42, 333-342. [CrossRef]

75. Stylos, N.; Vassiliadis, C.A.; Bellou, V.; Andronikidis, A. Destination Images, Holistic Images and Personal Normative Beliefs: Predictors of Intention to Revisit a Destination. Tour. Manag. 2016, 53, 40-60. [CrossRef]

76. Barnes, S.J.; Mattsson, J.; Sørensen, F. Destination Brand Experience and Visitor Behavior: Testing a Scale in the Tourism Context. Ann. Tour. Res. 2014, 48, 121-139. [CrossRef]

77. Jiménez Barreto, J.; Rubio, N.; Campo Martínez, S. The Online Destination Brand Experience: Development of a SensorialCognitive-Conative Model. Int. J. Tour. Res. 2019, 21, 245-258. [CrossRef]

78. Boo, S.; Busser, J.; Baloglu, S. A Model of Customer-Based Brand Equity and Its Application to Multiple Destinations. Tour. Manag. 2009, 30, 219-231. [CrossRef]

79. Tsai, C.T.S.; Wang, Y.C. Experiential Value in Branding Food Tourism. J. Destin. Mark. Manag. 2017, 6, 56-65. [CrossRef]

80. Lai, M.Y.; Khoo-Lattimore, C.; Wang, Y. A Perception Gap Investigation into Food and Cuisine Image Attributes for Destination Branding from the Host Perspective: The Case of Australia. Tour. Manag. 2018, 69, 579-595. [CrossRef]

81. Richards, G. Food Experience as Integrated Destination Marketing Strategy. In Proceedings of the World Food Tourism Summit, Lisbon, Portugal, 8-11 April 2015.

82. Askegaard, S.; Kjeldgaard, D. Here, there, and Everywhere: Place Branding and Gastronomical Globalization in a Macromarketing Perspective. J. MacroMark. 2007, 27, 138-147. [CrossRef]

83. Fusté-Forné, F. Savouring Place: Cheese as a Food Tourism Destination Landmark. J. Place Manag. Dev. 2020, 13, 177-194. [CrossRef]

84. Pizzichini, L.; Temperini, V.; Gregori, G.L. Place Branding and Local Food Souvenirs: The Ethical Attributes of National Parks' Brands. J. Place Manag. Dev. 2020, 13, 163-175. [CrossRef]

85. Tsakiridou, E.; Boutsouki, C.; Zotos, Y.; Mattas, K. Attitudes and Behaviour towards Organic Products: An Exploratory Study. Int. J. Retail. Distrib. Manag. 2008, 36, 158-175. [CrossRef]

86. Modica, P.D.; Altinay, L.; Farmaki, A.; Gursoy, D.; Zenga, M. Consumer Perceptions towards Sustainable Supply Chain Practices in the Hospitality Industry. Curr. Issues Tour. 2020, 23, 358-375. [CrossRef]

87. Hair, J.F.; Black, W.C.; Babin, B.J.; Anderson, R.E. Multivariate Data Analysis. Vectors 2010, 23. [CrossRef] 
88. Alsetoohy, O.; Ayoun, B.; Arous, S.; Megahed, F.; Nabil, G. Intelligent Agent Technology: What Affects Its Adoption in Hotel Food Supply Chain Management? J. Hosp. Tour. Technol. 2019, 10, 286-310. [CrossRef]

89. Alsetoohy, O.; Ayoun, B. Intelligent Agent Technology: The Relationships with Hotel Food Procurement Practices and Performance. J. Hosp. Tour. Technol. 2018, 9, 109-124. [CrossRef]

90. Hair, J.F.; Sarstedt, M.; Hopkins, L.; Kuppelwieser, V.G. Partial Least Squares Structural Equation Modeling (PLS-SEM): An Emerging Tool in Business Research. Eur. Bus. Rev. 2014, 26, 106-121. [CrossRef]

91. Hair, J.F.; Ringle, C.M.; Sarstedt, M. PLS-SEM: Indeed a Silver Bullet. J. Mark. Theory Pract. 2011, 19, 139-152. [CrossRef]

92. Hair, J.F.; Sarstedt, M.; Ringle, C.M.; Mena, J.A. An Assessment of the Use of Partial Least Squares Structural Equation Modeling in Marketing Research. J. Acad. Mark. Sci. 2012, 40, 414-433. [CrossRef]

93. Henseler, J.; Ringle, C.M.; Sarstedt, M. A New Criterion for Assessing Discriminant Validity in Variance-Based Structural Equation Modeling. J. Acad. Mark. Sci. 2015, 43, 115-135. [CrossRef]

94. Fornell, C.; Larcker, D.F. Structural Equation Models with Unobservable Variables and Measurement Error: Algebra and Statistics. J. Mark. Res. 1981, 18, 382-388. [CrossRef]

95. Esfahbodi, A.; Zhang, Y.; Watson, G. Sustainable Supply Chain Management in Emerging Economies: Trade-Offs between Environmental and Cost Performance. Int. J. Prod. Econ. 2016, 181, 350-366. [CrossRef]

96. Mitchell, R.D. Seasonality in New Zealand Winery Visitation: An Issue of Demand and Supply. In Wine, Food, and Tourism Marketing; Routledge: Oxfordshire, UK, 2013. [CrossRef]

97. Guptill, A.; Wilkins, J.L. Buying into the Food System: Trends in Food Retailing in the US and Implications for Local Foods. Agric. Hum. Values 2002, 19, 39-51. [CrossRef]

98. Cholette, S.; Ungson, G.R.; Özlük, Ö.; Özşen, L. Exploring Purchasing Preferences: Local and Ecologically Labelled Foods. J. Consum. Mark. 2013, 30, 563-572. [CrossRef]

99. Bean, M.; Sharp, J.S. Profiling Alternative Food System Supporters: The Personal and Social Basis of Local and Organic Food Support. Renew. Agric. Food Syst. 2011, 26, 243-254. [CrossRef]

100. Hu, W.; Qing, P.; Batte, M.; Woods, T.; Ernst, S. What Is Local and for What Foods Does It Matter? Agric. Econ. 2013, 59, 454-466. [CrossRef]

101. Alderighi, M.; Bianchi, C.; Lorenzini, E. The Impact of Local Food Specialities on the Decision to (Re)Visit a Tourist Destination: Market-Expanding or Business-Stealing? Tour. Manag. 2016, 57, 323-333. [CrossRef] 